\title{
Külföldi kölcsön: A határon átnyúló munkaerö-kölcsönzés Magyarországon, különös tekintettel a harmadik országok állampolgárainak foglalkoztatására
}

\author{
Foreign Loan: Cross-Border Temporary Agency Work in Hungary, with Special \\ Regard to the Employment of Third-Country Nationals
}

\begin{abstract}
ABSZTRAKT
A munkaerő-kölcsönzés sajátossága, hogy a munkavállaló nem a vele munkaszerződést kötő kölcsönbeadónál fog ténylegesen munkát végezni, hanem egy harmadik félnél, a kölcsönvevőnél, akivel a munkaerő visszterhes átengedéséröl a kölcsönbeadó egy polgári jogi szerződést köt. A cikk összefoglalja, hogyan jelenhet meg nemzetközi elem ebben a háromoldalú munkaviszonyban. Így kitér arra, milyen szabályok alá esik, ha a kölcsönbeadó egy másik ország állampolgárával kiván munkaszerzödést kötni, és arra is, ha a kölcsönbeadó és a kölcsönvevő más államban letelepedett. Noha a magyar jog általában tiltja, hogy Magyarországon harmadik országbeli állampolgár kölcsönzésen keresztül dolgozzon, ezt a kivételek egyre bövülö köre mégis lehetóvé teszi. A cikk bemutatja, hogyan alakul a Magyarországon dolgozó harmadik országbeli kölcsönzött munkavállalók munkajogi és társadalombiztositási helyzete.
\end{abstract}

Kulcsszavak: munkaerö-kölcsönzés, munkavállalók szabad mozgása, kiküldetés (posting), harmadik országbeli állampolgár foglalkoztatása

\begin{abstract}
The special feature of temporary agency work is that the employee does not work for the agency which concludes the employment contract with them, but for a third party, the user company, with which the agency enters into a civil law contract for the remunerated transfer of workforce. The article summarises how an international element can appear in this tripartite employment relationship. It covers the rules under which an agency may conclude an employment contract with a foreign employee and also the cases where the agency and the user company are established in different states. Although Hungarian law generally prohibits third-country nationals to work in Hungary as agency workers, this is made possible by an expanding range of exceptions. The article explores the labour law and social security law situation of third-country agency workers in Hungary.
\end{abstract}

Keywords: temporary agency work, free movement of workers, posting of workers, employment of third country nationals

\footnotetext{
* Dr. Kártyás Gábor, egyetemi docens, Pázmány Péter Katolikus Egyetem, Jog- és Államtudományi Kar, Munkajogi Tanszék; e-mail: kartyas.gabor@jak.ppke.hu.
} 
A nemzetközi munkajogi tényállások kedvelöinek igazi csemege a határon átnyúló munkaerö-kölcsönzés. Ebben a háromoldalú munkaviszonyban ugyanis számos kombinációban elképzelhető a nemzetközi elem megjelenése. Az első alapeset, ha a munkavállaló egy másik állambeli kölcsönbeadóval köt munkaszerződést. A munkaerö-kölcsönzés sajátossága, hogy a munkavállaló nem a vele munkaszerződést kötő kölcsönbeadónál fog ténylegesen munkát végezni, hanem egy harmadik félnél, a kölcsönvevőnél, akivel a munkaerő visszterhes átengedéséröl a kölcsönbeadó egy polgári jogi szerződést köt. ${ }^{1}$ Azzal is nemzetközi jelleget kap a foglalkoztatás, ha a kölcsönvevő és a kölcsönbeadó más államokban letelepedett, ez a második alapeset. Emellett ezek az esetek kombinálhatóak is, azaz a másik állambeli kölcsönbeadó egy harmadik vagy az eredeti államba is kikölcsönözheti a munkavállalót.

A nemzetközi munkaerö-kölcsönzésben rejlö első „határátlépés” tehát az, ha a munkavállaló nem vele azonos honosságú kölcsönbeadóval szerződik. Ebben az esetben kérdéses, hogy milyen szabályok vonatkoznak a más állambeli személyek munkavállalására a kölcsönbeadó országában. Ha a nemzetközi elem abban jelenik meg, hogy a kölcsönvevő más országban van, akkor a jogi kérdés az, vajon nyújthat-e határon átnyúló szolgáltatást a kölcsönbeadó a célországba, illetve a kölcsönzött munkavállalók belépése kötött-e valamilyen munkavállalási engedélyhez. Különösen érdekes a két tényállás összekapcsolódása, amikor a kölcsönbeadónak engedélyeztetni kell a másik országbeli munkavállaló foglalkoztatását, majd további feltételeknek kell megfelelnie ahhoz, hogy őt egy harmadik országba kölcsönözze ki.

Attól függően, hogy mely országok érintettek a tényállásban, rengeteg, különböző jogi következményekkel járó helyzet képzelhető el. Ugyanakkor ez a sokféle eset leegyszerűsíthető egy alapsémára: a fő kérdés az, hogy a nemzetközi elem uniós tagállamok között valósul-e meg, vagy érintett benne egy harmadik ország is.

Ebben a tanulmányban a nemzetközi elemet tartalmazó munkaerö-kölcsönzésre vonatkozó szabályokat tekintem át, azokra az esetekre koncentrálva, ahol a tényállás a magyar jogot is érinti, mivel valamelyik fél magyar honosságú. Ezeket az 1. táblázat összegzi, amely röviden utal az adott tényállásra alkalmazandó föbb jogintézményekre is. Külön figyelmet érdemel a harmadik állambeli állampolgárok magyarországi kikölcsönzése, amely bár föszabály szerint tilos, fontos kivételek révén a gyakorlatban mégis sokszor előfordul. E körben kitérek a Magyarországon foglalkoztatott, harmadik állambeli kölcsönzött munkavállalók jogi státuszára is.

${ }^{1}$ A kölcsönbeadó és a kölcsönvevő közötti jogi kapcsolat minősítése régóta vitatott a magyar szakirodalomban, lásd különösen: PRUGBERGER Tamás: Munkajog a polgári jogban a globalizálódó gazdasági viszonyok között (tanulmánygyüjtemény). DE KTK, Debrecen, 2006, 95; a kommentárirodalomban: Kardkovács Kolos (szerk.): A Munka Törvénykönyvének magyarázata. HVG-ORAC, Budapest, 2012, 383-396. 
1. táblázat. A nemzetközi elem megjelenése a munkaerő-kölcsönzésben²

\begin{tabular}{|c|c|c|c|c|}
\hline \multicolumn{3}{|c|}{ A felek honossága } & \multicolumn{2}{|c|}{ Alkalmazandó jogintézmények } \\
\hline Munkavállaló & Kölcsönbeadó & Kölcsönvevő & a munkavállalásra & a kikölcsönzésre \\
\hline \multirow{9}{*}{ HUN } & \multirow{3}{*}{ HUN } & HUN & \multirow{3}{*}{ belső jogi tényállás } & belső jogi tényállás \\
\hline & & EU & & kiküldetés \\
\hline & & 3. állam & & $\begin{array}{l}\text { A 3. állam joga } \\
\text { szerint lehetséges. }\end{array}$ \\
\hline & \multirow{3}{*}{ EU } & HUN & \multirow{3}{*}{ szabad mozgás joga } & kiküldetés \\
\hline & & EU & & belső jogi tényállás \\
\hline & & 3. állam & & $\begin{array}{l}\text { A 3. állam joga } \\
\text { szerint lehetséges. }\end{array}$ \\
\hline & \multirow{3}{*}{ 3. állam } & HUN & \multirow{3}{*}{$\begin{array}{l}\text { 3. államban } \\
\text { engedélyköteles } \\
\text { lehet. }\end{array}$} & $\begin{array}{l}\text { Kizárt (nincs } \\
\text { belföldi székhely). }\end{array}$ \\
\hline & & EU & & $\begin{array}{l}\text { Adott tagállam } \\
\text { szabályaitól függ. }\end{array}$ \\
\hline & & 3. állam & & belső jogi tényállás \\
\hline \multirow{9}{*}{ EU } & \multirow{3}{*}{ HUN } & HUN & \multirow{3}{*}{ szabad mozgás joga } & belső jogi tényállás \\
\hline & & EU & & kiküldetés \\
\hline & & 3. állam & & $\begin{array}{l}\text { A 3. állam joga } \\
\text { szerint lehetséges. }\end{array}$ \\
\hline & \multirow{3}{*}{ EU } & HUN & szabad mozgás joga & kiküldetés \\
\hline & & EU & \multicolumn{2}{|c|}{ Nem releváns a magyar jogban. } \\
\hline & & 3. állam & \multicolumn{2}{|c|}{ Nem releváns a magyar jogban. } \\
\hline & \multirow{3}{*}{ 3. állam } & HUN & $\begin{array}{l}\text { 3. államban engedély- } \\
\text { köteles lehet. }\end{array}$ & $\begin{array}{l}\text { Kizárt (nincs } \\
\text { belföldi székhely). }\end{array}$ \\
\hline & & EU & \multicolumn{2}{|c|}{ Nem releváns a magyar jogban. } \\
\hline & & 3. állam & \multicolumn{2}{|c|}{ Nem releváns a magyar jogban. } \\
\hline \multirow{9}{*}{ 3. állam } & \multirow{3}{*}{ HUN } & HUN & \multirow{3}{*}{$\begin{array}{l}\text { Főszabály } \\
\text { szerint nem } \\
\text { engedélyezhető. }\end{array}$} & belső jogi tényállás \\
\hline & & EU & & kiküldetés \\
\hline & & 3. állam & & $\begin{array}{l}\text { A 3. állam joga } \\
\text { szerint lehetséges. }\end{array}$ \\
\hline & \multirow{3}{*}{ EU } & HUN & $\begin{array}{l}\text { EU tagállamban } \\
\text { engedélyköteles lehet. }\end{array}$ & kiküldetés \\
\hline & & EU & \multicolumn{2}{|c|}{ Nem releváns a magyar jogban. } \\
\hline & & 3. állam & \multicolumn{2}{|c|}{ Nem releváns a magyar jogban. } \\
\hline & \multirow{3}{*}{ 3. állam } & HUN & belső jogi tényállás & $\begin{array}{l}\text { Kizárt (nincs } \\
\text { belföldi székhely) }\end{array}$ \\
\hline & & EU & \multicolumn{2}{|c|}{ Nem releváns a magyar jogban. } \\
\hline & & 3. állam & \multicolumn{2}{|c|}{ Nem releváns a magyar jogban. } \\
\hline
\end{tabular}

Forrás: saját szerkesztés

${ }^{2}$ HUN: magyar, EU: EGT-tagállam. 


\section{Toborzás egy másik uniós tagállamból: a munkavállalók szabad mozgása}

A munkaerö-kölcsönzésben a nemzetközi elem megjelenésének első oka az lehet, hogy a munkavállaló egy másik országban letelepedett kölcsönbeadóval köt munkaszerződést. Az uniós tagállamok vonatkozásában ez az eset első ránézésre semmilyen problémát nem vethet fel, hiszen - a szabad mozgás jogának lényege szerint - minden uniós polgár az adott tagállam állampolgáraival azonos feltételekkel létesíthet munkaviszonyt bármely másik tagállamban. ${ }^{3} \mathrm{Az}$ uniós jog nemcsak az állampolgárságon alapuló közvetlen és közvetett diszkriminációt tiltja, de azokat a tényállásokat is, amelyek ugyan nem tesznek különbséget az állampolgárság alapján, de hatásukban egyértelmüen akadályozzák a mozgásszabadságot. ${ }^{4} \mathrm{~A}$ munkaerő-kölcsönzésröl szóló irányelv (a továbbiakban: kölcsönzési irányelv) ${ }^{5}$ átültetése óta pedig a munkaerö-kölcsönzés minden tagállamban legális foglalkoztatási forma. Annak tehát semmi akadálya, hogy egy magyar kölcsönvevő más tagállambeli uniós polgárt alkalmazzon, akár magyar, akár más tagállamban letelepedett kölcsönbeadón keresztül. Úgyszintén lehetséges, hogy egy magyar kölcsönbeadó foglalkoztassa magyar munkavállalóját egy másik tagállamban. Az Európai Unió Bírósága (a továbbiakban: EUB) gyakorlata szerint a munkaerő szabad áramlásának elve a munkáltatók szempontjából is érvényesítendő, azaz bármely munkáltató toborozhat munkaerőt egy másik tagállam állampolgárai közül. ${ }^{6}$ Ez a kölcsönbeadók vonatkozásában is irányadó, nincs tehát akadálya, hogy a kölcsönbeadó egy másik tagállamban letelepedett munkavállalót kölcsönözzön.

Ugyanakkor a szabad mozgás jogát az új tagállamok vonatkozásában a csatlakozási szerződések bizonyos tagállamok vonatkozásában áttörhetik, fenntartva a csatlakozáskor hatályos szabályokat. A 2004-es keleti kibővítést követő átmeneti időszakban két esetben is felmerült, hogy vajon köthető-e munkavállalási engedélyhez, ha egy új (EU10) tagállambeli kölcsönbeadó valamely korábbi (EU15) tagállambeli

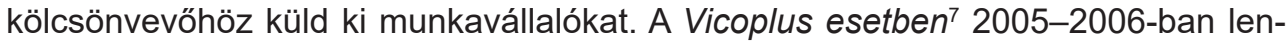
gyel kölcsönzött munkavállalók dolgoztak Hollandiában, munkavállalási engedély nélkül, ami miatt a holland hatóságok bírsággal éltek a kölcsönbeadóval szemben. Jóllehet a 2003. évi csatlakozási okmány lehetővé tette, hogy a munkavállalók szabad mozgását a régi tagállamok korlátozzák, kérdéses volt, hogy ez vajon vonatkozik-e arra, ha az új tagállambeli kiküldött munkavállaló munkaerő-kölcsönzés kereté-

\footnotetext{
${ }^{3}$ Az Európai Unió Működéséről szóló Szerződés 45. cikk; az Európai Parlament és a Tanács 492/2011/EU rendelete (2011. április 5.) a munkavállalók Unión belüli szabad mozgásáról. HL L 141, 2011.5.27., 1-12.

${ }^{4}$ GelLÉRnÉ LUKÁCs Éva: Az egyenlő bánásmód, a nem diszkriminatív akadályok és az intézményesített jogvédelem fejlődése a személyek szabad mozgása területén. Állam- és Jogtudomány, 2020/3, 64.

${ }^{5}$ Az Európai Parlament és a Tanács 2008/104/EK irányelve (2008. november 19.) a munkaerő-kölcsönzés keretében történő munkavégzésröl. HL L 327, 2008.12.5., 9-14.

${ }^{6}$ C-350/96. sz. Clean Car Autoservice GesmbH kontra Landeshauptmann von Wien ügyben 1998. május 7-én hozott ítélet [EU:C:1998:205], különösen 19-21. pont; C-208/05. sz., Innovative Technology Center GmbH kontra Bundesagentur für Arbeit ügyben 2007. január 11-én hozott ítélet [EU:C:2007:16], 22-26. pont.

${ }^{7}$ C-307-309/09. sz. Vicoplus SC PUH, BAM Vermeer Contracting sp. zoo és Olbek Industrial Services sp. zoo kontra Minister van Sociale Zaken en Werkgelegenheid egyesített ügyekben 2011. február 11-én hozott ítélet [EU:C:2011:64].
} 
ben lép be a régi tagállamok területére. Ilyenkor ugyanis a munkavállaló nem közvetlenül létesít foglalkoztatási jogviszonyt az adott országban, hanem a kölcsönbeadó által nyújtott szolgáltatás révén kerül az érintett tagállamba. A szolgáltatások szabad áramlásának korlátozását ugyanakkor csak Ausztria és Németország esetében tette lehetővé a csatlakozási szerződés. Az EUB, érzékelve a munkaerő-kölcsönzés sajátos jellegét, egyrészt leszögezte, hogy az az alapszabadságok szempontjából szolgáltatásnak minősül. Másrészt viszont hozzátette, hogy mivel itt a szolgáltatás maga a munkaerő rendelkezésre bocsátása, hatásában ugyanarról van szó, mintha az érintett munkavállaló közvetlenül lépne be az érintett tagállam munkaerőpiacára. Ezt az EUB megerősítve látta abban is, hogy a kölcsönzött munkavállalók olyan pozíciókban dolgoznak, amelyeket a kölcsönvevő közvetlenül is betölthetne. ${ }^{8}$ Ezért nem találta ellentétesnek az uniós joggal, ha a nemzeti szabályozás ehhez munkavállalási engedélyt követel meg.

Ugyanez a kérdés merült fel a magyar vonatkozású Martin Meat esetben. ${ }^{9}$ A tényállás szerint 2007-ben az osztrák hatóságok bírságot szabtak ki egy osztrák céggel szemben, mert az munkavállalási engedély nélkül foglalkoztatott magyar munkavállalókat, az osztrák hatóság álláspontja szerint munkaerő-kölcsönzés keretében. Az EUB megerősítette, hogy az ezt lehetővé tévő nemzeti szabályozás csak akkor fogadható el, ha a munkavállalók foglalkoztatására valóban munkaerö-kölcsönzés keretében került sor, ám ha csak egyszerü határon átnyúló szolgáltatásnyújtásról van szó, úgy ilyen korlátozás nem alkalmazható. ${ }^{10}$ Az EUB ezt a gyakorlatát később, a horvát csatlakozást követő átmeneti szabályok kapcsán is fenntartotta, kimondva, hogy a munkaerő-kölcsönzés keretében Ausztriába kiküldött horvát munkavállalóktól kérhető munkavállalási engedély. ${ }^{11}$

Hangsúlyozni kell, hogy a munkaerő-kölcsönzési szolgáltatás csak a csatlakozási szerződések szerinti külön felhatalmazás alapján, csak a munkaerő szabad áramlására kikötött átmeneti időben esik ilyen speciális elbírálás alá. Egyébként - a munkavállalás és a szolgáltatásnyújtás szabadságából eredően - tilos munkavállalási engedélyt előírni a más tagállamból érkezett kölcsönzött munkavállalókkal szemben.

\section{Kikölcsönzés egy másik tagállamba: kiküldetés (posting) kölcsönzésen keresztül}

A munkaerő-kölcsönzés akkor is nemzetközi vonatkozást kap, ha a munkaszerződés ugyan azonos honosságú felek között jön létre, de a tényleges munkavég-

${ }^{8}$ C-307-309/09. Vicoplus, 27., 31-32., 35. pontok.

${ }^{9}$ C-586/13. sz. Martin Meat Kft. kontra Géza Simonfay és mások ügyben 2015. június 18-án hozott ítélet [EU:C:2015:405].

${ }^{10} \mathrm{C}-586 / 13$. Martin Meat, 30. pont. A Vicoplus és a Martin Meat ügy további jelentősége, hogy támpontokat adott a munkaerő-kölcsönzés és a szolgáltatásnyújtás keretében megvalósuló kiküldetés mint a kiküldetési irányelv szerinti posting két tényállásának elhatárolásához.

${ }^{11}$ C-18/17. sz. Danieli \& C. Officine Meccaniche SpA és társai kontra Regionale Geschäftsstelle Leoben des Arbeitsmarktservice ügyben 2018. november 14-én hozott ítélet [EU:C:2018:904]. 
zésre egy másik tagállamban letelepedett kölcsönvevőnél kerül sor ${ }^{12}$ (például az osztrák kölcsönbeadó az osztrák állampolgárt kölcsönzi egy magyarországi kölcsönvevőhöz). Az uniós jogban a kiküldetési irányelv ${ }^{13}$ értelmében ez a tényállás a szolgáltatásnyújtás keretében megvalósuló kiküldetés (posting) egyik tényállásának minősül. ${ }^{14} \mathrm{Az}$ irányelv lényege az, hogy noha a kölcsönzött munkavállaló továbbra is a szokásos munkavégzési hely szerinti állam jogának hatálya alatt marad, a fogadó tagállam munkajogi szabályait kell alkalmazni az irányelv 3. cikkében meghatározott körben, ha ez a munkavállalóra nézve kedvezőbb. E cikk a legalapvetőbb munkafeltételeket rögzíti, így a kötelező díjazási elemeket, a fizetett szabadság mértékét, a minimális pihenőidőket, de ide tartoznak a munkavállalók munkaerő-kölcsönzés keretében történő rendelkezésre bocsátásának feltételeire vonatkozó szabályok is. Ez utóbbi azt jelenti, hogy a kölcsönvevő székhelye szerinti tagállam munkajogi szabályaiból a kölcsönzött munkavállalót védő törvényi garanciák is alkalmazandóak, ha ezek az egyébként irányadó jognál kedvezőbbek. Nincs tehát mód arra, hogy a munkaerő-kölcsönzést rugalmasan szabályozó tagállamok kölcsönbeadói illetéktelen előnyhöz jussanak egy olyan másik tagállam piacán, ahol a kölcsönzött munkavállalót szigorúbb törvényi védelem illeti meg.

Ha a kiküldetés munkaerö-kölcsönzés keretében valósul meg, az bizonyos részletszabályok tekintetében speciális elbírálás alá esik. A legfontosabb, hogy a kiküldetési irányelvben a kölcsönzéshez kötődik egy speciális kivétel, a kiküldött munkavállalóra alkalmazandó munkajogi szabályok kapcsán. Eszerint a tagállamok dönthetnek úgy, hogy a munkaerő-kölcsönzés keretében kiküldött munkavállalókra az „ideiglenes munkavállalókra" vonatkozó előírásokat is alkalmazzák. ${ }^{15}$ A szabály gyakorlatilag értelmezhetetlen, hiszen a „munkavállalók rendelkezésre bocsátásának feltételei” amúgy is szerepelnek a fogadó állam munkajogából kötelezően alkalmazandó szabályok között. ${ }^{16}$ Ehhez képest kétséges, hogy milyen (további) szabályokra utal a jogalkotó az „ideiglenes munkavállalók” kapcsán. A szó szerinti értelmezés alapján e szűk személyi körre a belső jog „ideiglenes munkavállalókra” vonatkozó része teljes egészében kiterjeszthető lehet. Ez az értelmezés azonban soha nem merült fel a munkaerő-kölcsönzéssel kapcsolatos esetjogban. Különösen figyelemreméltó, hogy mindezek ellenére ez a kivétel érdemi változtatás nélkül megmaradt a kiküldetési irányelv 2018-as módosítása után is. ${ }^{17}$

A kiküldetési irányelv módosított szövege emellett kifejezetten rendezi a továbbkölcsönzés esetét. Ebben az esetben a munkavállalót nem a kölcsönbeadó, hanem

\footnotetext{
12 Rodríguez, Ricardo-Miranda Boto, José María-PARIS, Jean Jacques: Setting up a European Observatory on cross-border activities within temporary agency work. Labour Asociados S.L.L., Uni-Europa, Euro-Ciet, 2010, 12-13.

${ }^{13}$ Az Európai Parlament és a Tanács 96/71/EK irányelve (1996. december 16.) a munkavállalók szolgáltatások nyújtása keretében történő kiküldetéséröl. HL L 18, 1997.1.21., 1-6. (a továbbiakban: kiküldetési irányelv).

14 Kiküldetési irányelv 1. cikk (3) bek. c) pont.

15 Kiküldetési irányelv 3. cikk (9) bek.

${ }^{16}$ Kiküldetési irányelv 3. cikk (1) bek. d) pont. PedersinI, Roberto-Pallini, Massimo: Posted workers in the European Union. Eurofound Report, 2010, 22.

${ }^{17}$ Az Európai Parlament és a Tanács (EU) 2018/957 irányelve (2018. június 28.) a munkavállalók szolgáltatások nyújtása keretében történő kiküldetéséről szóló 96/71/EK irányelv módosításáról. HL L 173, 2018.7.9., 16-24. (a továbbiakban: módosító irányelv) 1. cikk 2. e) pont.
} 
a kölcsönvevő küldi ki egy másik tagállamba. Az új szabály alapján - a munkavállalók védelme érdekében ${ }^{18}$ - a kiküldetéssel kapcsolatos munkáltatói kötelezettségekért továbbra is a kölcsönbeadó felelős. ${ }^{19}$ Meg kell jegyezni, hogy mivel a munkaviszony a kölcsönbeadóval áll fenn, ${ }^{20}$ álláspontom szerint ez következett a módosítás előtti szövegböl is. ${ }^{21}$

Ezen túl a módosító irányelv deklarálja, hogy a kiküldött kölcsönzött munkavállaló is jogosult a (külföldi) kölcsönvevő saját munkavállalóival egyenlő bánásmódra, ahogy azt a kölcsönzési irányelv előírja. Az irányadó munkafeltételekről a kölcsönvevőnek kötelező tájékoztatást adnia a kölcsönbeadónak. ${ }^{22}$ Véleményem szerint ezt is szükségtelen külön rögzíteni a normaszövegben. A kiküldetési irányelv szerint ugyanis a munkavállalók rendelkezésre bocsátásának (kikölcsönzésének) feltételei ma is a kiküldött munkavállalóra alkalmazandó szabályok között szerepelnek. ${ }^{23} \mathrm{Nyil}-$ vánvalóan ide tartoznak a kölcsönzési irányelv által megkövetelt egyenlő bánásmóddal kapcsolatos nemzeti rendelkezések is ${ }^{24}$ valamennyi tagállamban.

A határon átnyúló munkaerő-kölcsönzés az uniós jogban a szociális biztonsági rendszerek koordinációja szempontjából is fontos értelmezési kérdéseket vetett fel. A szociális biztonsági koordináció egyik alapelve, hogy a nemzetközi tényállásoknál mindig világosan meghatározható legyen, mely tagállam jogrendszerét kell alkalmazni a munkavállalóra, azzal, hogy egy időben mindig csak egy alkalmazandó jogrendszer lehet. ${ }^{25}$ Ez föszabály szerint a munkavégzés helye szerinti jog (lex loci laboris). ${ }^{26}$ Ám ha egy munkavállaló elhagyja a szokásos munkavégzési helyét, és munkáltatója nevében átmenetileg, legfeljebb 24 hónapig egy másik tagállamban végez munkát, akkor az eredeti tagállam rendszerének hatálya alatt marad (ez a kiküldetés fogalma a szociális biztonsági koordinációban). ${ }^{27}$

Figyelmet érdemel, hogy az EUB hogyan értelmezte ez utóbbi szabályt a munkaerő-kölcsönzés speciális konstrukciójára tekintettel. A Fitzwilliam eset ${ }^{28}$ tényállása szerint egy ír cég kölcsönzött munkavállalókat foglalkoztatott Írországban és Hollandiában. Valamennyi munkavállalója ír állampolgár volt, akik Írországban rendel-

${ }^{18}$ Módosító irányelv Preambulum (13).

${ }^{19}$ A kölcsönvevő a kiküldetés előtt köteles kellő időben tájékoztatni a kölcsönbeadót a más tagállambeli munkavégzésröl. A módosító irányelvvel megállapított 1. cikk (3) bek. 2. albek.

${ }^{20}$ Kölcsönzési irányelv 3. cikk (1) bek. b) pont; kiküldetési irányelv 1. cikk (3) bek. c) pont.

${ }^{21}$ Említést érdemel, hogy a kiküldött munkavállalók munkafeltételei kapcsán speciális tájékoztatási kötelezettséget ír elő az Európai Unióban alkalmazandó átlátható és kiszámítható munkafeltételekről szóló $2019 / 1152$ irányelv 7. cikke is. Elemzését lásd: PRUGBERGER Tamás-TóTH Hilda: A munkáltatók munkavállalók irányában fennálló tájékoztatási kötelezettségének várható alakulása az átlátható és kiszámítható munkafeltételekről szóló új irányelv alapján. Magyar jog, 2020/1, 36-38.

${ }^{22}$ A módosító irányelvvel megállapított 3. cikk (1b) bek., kölcsönzési irányelv 5. cikk.

${ }^{23}$ Kiküldetési irányelv 3. cikk (1) bek. d) pont.

24 Kölcsönzési irányelv 5. cikk.

25 GeLLÉRNÉ LUKÁcs Éva-KovÁcs Réka: Szociális biztonsági koordináció és munkaerőmozgás - az Alpenrindeset és az Osztrák Legfelsőbb Közigazgatási Bíróság ítélete. Európai Tükör, 2019/3, 81.

${ }^{26}$ Az Európai Parlament és a Tanács 883/2004/EK rendelete (2004. április 29.) a szociális biztonsági rendszerek koordinálásáról. HL L 166, 2004.4.30., 1-123, 11. cikk (1) bek.

27 883/2004/EK rendelet 12. cikk.

${ }^{28}$ C-202/97. sz. Fitzwilliam Executive Search Ltd kontra Bestuur van het Landelijk instituut sociale verzekeringen ügyben 2000. február 10-én hozott ítélet [EU:C:2000:75]. 
keztek lakóhellyel, és akikkel a munkaszerződést is itt kötötték meg. Az ír cég az átmenetileg Hollandiába kikölcsönzött munkavállalói után nem a holland, hanem az ír szabályok szerint fizette a társadalombiztosítási járulékokat. Ezt a gyakorlatot a holland hatóságok vitatták, mivel álláspontjuk szerint a cég Írországban nem végzett érdemi tevékenységet. 22 belsős munkavállalója közül ugyan csak ketten dolgoztak a holland irodában, 1993 és 1996 között a cég bevételének nagyobbik részét Hollandiában szerezte. Az EUB ítéletében az ideiglenes kiküldetésekre vonatkozó kivételt a munkaerő-kölcsönzés esetén is irányadónak tekintette, azonban alkalmazásához egy további feltételt támasztott. Eszerint a kivétel a munkaerö-kölcsönző vállalkozásra csak akkor alkalmazható, ha a székhelye szerinti tagállamban rendszeres, jelentős tevékenységet végez. $E$ feltétel mindig csak az eset összes körülményei alapján vizsgálható, az EUB csak példálózó felsorolást adott az elbírálásnál figyelembe vehető szempontokról. ${ }^{29} \mathrm{~A}$ Fitzwilliam ítélet alapján tehát nem kerülhető meg a fogadó ország szociális biztonsági rendszere azzal, hogy a munkáltató munkavállalóit egy kizárólag e célra létrehozott külföldi kölcsönbeadón (ún. postaláda cégen) keresztül foglalkoztatja, mely cég más érdemi tevékenységet a székhely szerinti államban nem végez. A lényegi tevékenység végzésének vizsgálata a kiküldetési kivétel alkalmazhatóságának alapvető feltétele munkaerő-kölcsönzés esetén. ${ }^{30}$

Ehhez az értelmezéshez az EUB máig következetes maradt, ${ }^{31}$ alkalmazását pedig később ki is bővítette. A Plum ítéletben ${ }^{32}$ nemcsak a munkaerő-kölcsönzés kapcsán, hanem általánosságban is kimondta, hogy a munkáltató az ideiglenes kiküldetésekre vonatkozó kivételre nem hivatkozhat, ha tevékenysége a székhelye szerinti tagállamban kizárólag belső ügyintézési feladatokra korlátozódik, és minden érdemi tevékenységét a kiküldetés helye szerinti tagállamban végzi. A Banks-ügyben ${ }^{33}$ ugyanezt az elvet alkalmazta egy ideiglenesen más tagállamban dolgozó önfoglalkoztató esetére is. A kiküldő (a kölcsönbeadó székhelye szerinti) államban végzett érdemi tevékenység megkövetelése ma már a joggyakorlat szerves része, amelyet a 2001/891/EK határozat is megerősített. ${ }^{34} \mathrm{Az}$ érdemi tevékenység vizsgálatához a

${ }^{29}$ Például a székhely és központi ügyintézés helye, az alkalmazott belsős munkavállalók létszáma, a kiküldött munkavállalók toborzásának helye, a kölcsönvevőkkel való szerződéskötések helye, a munkaszerződésekre és a kölcsönvevővel kötött szerződésekre alkalmazandó jog, a bevétel aránya stb. (C-202/97. Fitzwilliam, 40., 43., 45. pont).

${ }^{30}$ Hungler Sára-Gellérné LukÁcs Éva-Petrovics Zoltán-Dudás Katalin: Az Európai Unió szociális és munkajoga. ELTE Eötvös, Budapest, 2020, 232.

${ }^{31}$ C-115/11. sz. Format Urządzenia i Montaże Przemysłowe sp. z o.o. kontra Zakład Ubezpieczeń Społecznych ügyben 2012. október 4-én hozott ítélet [EU:C:2012:606], 32. pont; C-2/05. sz. Rijksdienst voor Sociale Zekerheid kontra Herbosch Kiere NV. ügyben 2006. január 26-án hozott ítélet [EU:C:2006:69], 19. pont.

32 C-404/98. sz. Josef Plum kontra Allgemeine Ortskrankenkasse Rheinland, Regionaldirektion Köln ügyben 2000. november 9-én hozott ítélet [EU:C:2000:607], 21-23. pont.

${ }^{33}$ C-178/97. sz. Barry Banks és mások kontra Theatre royal de la Monnaie ügyben 2000. március 30-án hozott ítélet [EU:C:2000:169].

${ }^{34}$ A Migráns Munkavállalók Szociális Biztonságával Foglalkozó Igazgatási Bizottság 2001/891/EK határozata (HL L 329, 2001.12.14., 73-77.), amely lényegében az EUB esetjogát összegezve ad példákat is a 12 (24) hónapos kivétel alkalmazásához. 
gyakorlat jó pár objektív szempontot alakított ki, ám ezeket mindig a maguk összességében, a konkrét ügy egyedi sajátossága (például a munkáltató tevékenysége) alapján kell értékelni. ${ }^{35}$

\section{Kombinált esetek: határon átnyúló munkavállalás és kiküldetés egyszerre}

Olyan tényállás is elképzelhető, ahol a határon átnyúló munkaerő-kölcsönzés alapesetei összekapcsolódnak. Azaz a kölcsönbeadó egy másik tagállamból toborozza a munkavállalókat, akiket egy harmadik tagállamban letelepedett kölcsönvevőhöz kölcsönöz ki. Ilyenkor a kölcsönbeadó székhelye és a tényleges munkavégzés helye szerinti tagállamban is figyelemmel kell lenni a munkaerő szabad áramlására vonatkozó szabályokra. Egy további tényállástípust jelent, ha a munkavállaló és a kölcsönvevő honossága azonos, csak a kölcsönbeadó székhelye van egy másik tagállamban. A Fitzwilliam és különösen a Plum esetböl nyilvánvaló, hogy ezzel nem kerülhető ki visszaélésszerüen a kölcsönvevő székhelye szerinti szociális biztonsági rendszer hatálya.

Külön figyelmet érdemel az az eset, ha a más tagállambeli kölcsönbeadó által kikölcsönzött munkavállaló harmadik állambeli állampolgár. Az EUB előtt több esetben felmerült a kérdés, hogy a szolgáltatást fogadó tagállam vajon megkövetelhet-e munkavállalási engedélyt a területére kiküldött (kölcsönzött) harmadik állambeli munkavállalóktól. Az 1994-es Vander Elst ügyben ${ }^{36}$ négy marokkói építőmunkás dolgozott Franciaországban, akik Belgiumban - a munkáltatójuk székhelye szerinti országban - rendelkeztek munkavállalási engedéllyel és biztosítási jogviszonnyal. A francia hatóságok mégis megbírságolták a kiküldő munkáltatót a francia munkavállalási engedély hiánya és a francia egészségbiztosítási járulék megfizetésének elmaradása miatt. Az EUB megállapította, hogy a kiküldött munkavállalók „nem lépnek be" a fogadó ország munkaerőpiacára, ott csak ideiglenesen jelennek meg, ezért velük szemben aránytalanul szigorú ellenőrző intézkedéseket nem lehet alkalmazni. Emellett a kiküldött munkavállalók a francia hatóságok által hiányolt követelményeknek Belgiumban már megfeleltek, márpedig ez kizárja, hogy a munkavállalók kizsákmányolásának vagy a verseny torzításának megakadályozása céljából Franciaországban újra teljesíteni kelljen ezeket a feltételeket. ${ }^{37} \mathrm{Az}$ EUB ezt a gyakorlatot később is megerősítette, hangsúlyozva, hogy a munkavállaló védelme és a munkaerőpiac zavartalansága mint közérdek azzal is előmozdítható, ha - engedélyezés helyett - a harmadik országbeli kiküldött munkavállaló foglalkoztatását csak bejelentéshez köti a fogadó tagállam. ${ }^{38}$

35 HAJdú József-BERKI Gabriella-Ács Vera-JANINÉ LAdos Dóra: Szabad mozgás és az Európai Unió szociális joga. [k. n.] Szeged, 2015, 74. http://www.juris.u-szeged.hu/download.php?doclD=57187 (2021. 05. 18.).

${ }^{36}$ C-43/93. sz. Raymond Vander Elst kontra Office des migrations internationales ügyben 1994. augusztus 9-én hozott ítélet [EU:C:1994:310].

${ }_{37} \mathrm{C}-43 / 93$. Raymond Vander Elst, 21., 25. pont.

${ }^{38}$ C-445/03. sz. Európai Közösségek Bizottsága kontra Luxemburgi Nagyhercegség ügyben 2004. október 21-én hozott ítélet [EU:C:2004:655], 31., 46. pont; C-244/04. sz. Európai Közösségek Bizottsága kontra 
A töretlen bírói gyakorlat alapján tehát, ha a harmadik állambeli állampolgár egy uniós tagállamban jogszerüen tartózkodik és vállal munkát, akkor egy másik tagállamba is kiküldhető - akár kölcsönzésen keresztül - ideiglenes munkavégzésre. Ezt pedig a fogadó állam nem korlátozhatja (újabb) munkavállalási engedély előírásával. A szakirodalom találóan ezt nevezi „másodlagos szabad mozgáshoz való jognak". ${ }^{39}$ Meg kell ugyanakkor jegyezni, hogy az EUB alaptétele, miszerint a kiküldött munkavállaló „nem lép be” a fogadó állam munkaerőpiacára, meglehetősen vitatható. Az uniós jog ugyanis egészen a kiküldetési irányelv módosításának hatálybalépéséig nem írt elő konkrét időkorlátot a kiküldetésre, ${ }^{40}$ arra pedig mind a mai napig nincs előírás, hogy egy kiküldött munkavállaló a kiküldetése lejártakor köteles lenne visszatérni a kiküldő tagállamba, és ne folytathatná karrierjét a fogadó államban, ezúttal közvetlen munkaviszonyt létesítve egy helyi munkáltatóval.

\section{Harmadik országbeli állampolgárok kölcsönzése Magyarországra}

A harmadik országbeli állampolgárok főszabály szerint munkaerő-kölcsönzés keretében nem dolgozhatnak Magyarországon. Noha ilyen generális tilalmat egyetlen jogszabályunk sem állít, a magyarországi munkavégzés engedélyezésére vonatkozó szabályozásból erre a következtetésre kell jutnunk. Ugyanakkor, a szabályozás útvesztőinek áttekintéséből az is világos lesz, hogy ez alól a tilalom alól van néhány fontos kivétel.

Leegyszerűsítve, a harmadik országbeli állampolgár magyarországi munkavállalásának engedélyezése összevont kérelmezési eljárásban történik, amelynek során a tartózkodás és a munkavállalás engedélyezésének körülményeit egy egységes eljárásban vizsgálják. ${ }^{41}$ Ebben az eljárásban a megyei (fővárosi) kormányhivatal szakhatóságként vesz rész, és nyilatkozik arról, hogy - a munkaerőpiaci helyzet vizsgálata alapján - támogatja-e a harmadik országbeli állampolgár adott munkakörben

Németországi Szövetségi Köztársaság ügyben 2006. január 19-én hozott ítélet [EU:C:2006:49], 41. pont; C-168/04. sz. Európai Közösségek Bizottsága kontra Osztrák Köztársaság ügyben 2006. szeptember 21-én hozott ítélet [EU:C:2006:595], 52., 57. pont. Kifejezetten a kölcsönzést érintő esetek voltak: C-91/13. sz. Essent Energie Productie BV kontra Minister van Sociale Zaken en Werkgelegenheid ügyben 2014. szeptember 11-én hozott ítélet [EU:C:2014:2206], 57-59. pont; C-18/17. Danieli, 49-52. pont.

${ }^{39}$ HouwerzIJL, Mijke: Towards a More Effective Posting Directive. In: Blanpain, Roger (szerk.): Freedom of Services in the European Union. Labour and Social Security Law: The Bolkestein Initiative. Wolters Kluwer, 2006, 182.

${ }^{40}$ Az új szabály alapján a kiküldetés 12 hónap lehet, amely a kiküldő munkáltató kérelmére 6 hónappal meghosszabbítható. Ha a kiküldetés ennél hosszabb ideig tart, akkor - az irányelvben előírt kivételekkel - immár teljes egészében a fogadó állam jogát kell alkalmazni a munkavállalóra. Módosított kiküldetési irányelv 3. cikk (1a) bek.

41 2007. évi II. törvény a harmadik országbeli állampolgárok beutazásáról és tartózkodásáról (a továbbiakban: Harmtv.) 2. § w) pont. Az Európai Parlament és a Tanács 2011/98/EU irányelve (2011. december 13.) a harmadik országbeli állampolgárok valamely tagállam területén való tartózkodására és munkavállalására vonatkozó összevont engedélyre irányuló összevont kérelmezési eljárásról, valamint a harmadik országból származó, valamely tagállam területén jogszerűen tartózkodó munkavállalók közös jogairól. HL L 343 , 2011.12.23., 1-9. 
való foglalkoztatását. ${ }^{42} \mathrm{Az}$ eljárás lényege annak megvizsgálása, hogy a harmadik országbeli állampolgár foglalkoztatása jelent-e veszélyt a magyar vagy EGT állampolgárok magyarországi munkavállalására. ${ }^{43} \mathrm{Ha}$ a harmadik országbeli állampolgár foglalkoztatása nem támogatott, akkor az összevont engedély nem adható ki. ${ }^{44}$ Az elutasításnak számos lehetséges indokát sorolja fel a jogszabály, ezek egy része a szakhatóság mérlegelésétől függ, míg mások fennállása esetén támogató állásfoglalás nem adható ki. Ez utóbbi, kötelező elutasítást eredményező körülmények között szerepel, ha a harmadik országbeli állampolgár magyarországi foglalkoztatása munkaerö-kölcsönzést valósít meg. ${ }^{45}$ Ebben az esetben tehát összevont eljárás keretében a magyarországi munkavégzés nem engedélyezhető.

Ugyanerre a következtetésre juthatunk akkor is, ha nincs lehetöség az összevont kérelmezési eljárásra, hanem a tartózkodási engedély kérelmezése mellett a harmadik állambeli állampolgárnak külön kell munkavállalási engedélyt is kérnie (például azoknak, akik au pairként vagy tengerészként, tanulmányok folytatása céljából vagy 180 napon belül 90 napot meg nem haladó időtartamra kívánnak Magyarország területén tartózkodni). ${ }^{46} \mathrm{~A}$ kormányhivatal ugyanis köteles az engedély iránti kérelmet elutasítani, ha a harmadik országbeli állampolgár foglalkoztatására nem a kérelmet benyújtó foglalkoztatónál kerül sor, vagy a foglalkoztatásra irányuló jogviszony nem a kérelmet benyújtó foglalkoztató és a harmadik országbeli állampolgár között jön létre, illetve ha a szolgáltatás kizárólagos tárgya a külföldi munkáltatóval kötött magánjogi szerződésben a harmadik országbeli állampolgár munkaerejének tartós átengedése. ${ }^{47}$ Mivel munkaerö-kölcsönzés esetén a tényleges munkavégzés a kölcsönvevőnél valósul meg, aki viszont nem áll közvetlenül foglalkoztatásra irányuló jogviszonyban a munkavállalóval, illetve a szolgáltatás fogalmilag a munkaerő átengedésére irányul, a munkaerö-kölcsönzés esetén munkavállalási engedély sem adható. ${ }^{48} \mathrm{~A}$ szabályozásban azonban a kölcsönzésen keresztüli foglalkoztatás általános tilalma alól több kivételt is találhatunk.

Egyrészt, szezonális munka munkaerö-kölcsönzés keretében is engedélyezhető. A szezonális munka olyan tevékenység, amely a naptári év bizonyos szakaszához kötődik, az adott évszak feltételeihez kapcsolódó, ismétlődő esemény vagy

${ }^{42}$ A harmadik országbeli állampolgárok magyarországi foglalkoztatásának nem összevont kérelmezési eljárás alapján történő engedélyezéséről, az engedélyezési kötelezettség alóli mentességről, a fővárosi és megyei kormányhivatal munkaügyi központjának az összevont kérelmezési eljárásban való szakhatósági közreműködéséről, valamint a Magyarországon engedélymentesen foglalkoztatható harmadik országbeli állampolgárok magyarországi foglalkoztatásának bejelentéséről, és a munkabér megtérítéséről szóló 445/2013. (XI. 28.) Korm. rendelet (a továbbiakban: Korm. rend.).

${ }^{43}$ Ács Vera Judit: Külföldiek magyarországi foglalkoztatása. Wolters Kluwer, Budapest, 2015, 64.

${ }^{44}$ Harmtv. 29/A. $§(7)$ bek.

${ }^{45}$ Korm. rend. 20. $\S(1)$ bek. k) pont.

${ }^{46}$ Harmtv. 29/A. § (4) bek., 2011/98/EU irányelv 3. cikk (2)-(3) bek.

${ }^{47}$ Korm. rend. 5. $\S(1)$ bek. f-h) pont. Kivételt képez, ha a belföldi foglalkoztatóval kötött megállapodás teljesítése érdekében a külföldi munkáltatóval fennálló jogviszonya alapján kerül sor a harmadik országbeli állampolgár foglalkoztatására, lásd 2. § 4. pont b) alpont. Ez lényegében a kiküldetési irányelv hatálya alá eső tényállás.

${ }^{48}$ KovÁcs Szabolcs-TAKÁcs Gábor: Kommentár a foglalkoztatási törvényhez. Wolters Kluwer, Budapest, 2015, 71-72. Lásd a kölcsönzés legális definícióját: Mt. 214. §. 
események sorozata miatt, amikor az általában zajló műveletek esetében jóval több munkaerőre van szükség. ${ }^{49}$ Noha ez a meghatározás meglehetősen tág és a tevékenységek egész sorát magában foglalja, a vonatkozó kormányrendelet a fogalmat leszükíti a mezőgazdaság foglalkoztatási ágazataiban végzett tevékenységre..$^{50}$ Szezonális munkavállalási engedéllyel a harmadik országbeli állampolgár foglalkoztatása nem haladhatja meg a folyamatos 90 napot, ugyanazon személynek kiadott több engedély esetén pedig 12 hónapon belül a 180 napot. ${ }^{51}$

A második kivétel az engedélymentes foglalkoztatás - gyakorlati szempontból talán legfontosabb esetéhez kötödik. Nem szükséges ugyanis a foglalkoztatás engedélyezése a Magyarországgal szomszédos harmadik ország állampolgárai esetén, akik lakóhelye ebben a szomszédos harmadik országban van, feltéve, hogy a munkavégzés a foglalkoztatáspolitikáért felelős miniszter közleményében meghatározott foglalkozásokban történik. Ez a munkavégzés pedig kifejezetten történhet munkaerő-kölcsönzés útján is. ${ }^{52} \mathrm{Ez}$ a szabály tehát a Szerbiában és Ukrajnában lakóhellyel rendelkező szerb és ukrán állampolgárokra vonatkozik, akik Magyarországon akár kölcsönzés keretében is dolgozhatnak, engedélymentesen, de csak a külön közzétett foglalkozásokban. E foglalkozások hatályos listáját a pénzügyminiszter a Hivatalos Értesítő 2019. évi 20. számában tette közzé. Fontos, hogy az engedélymentesség szigorúan csak a mentesség hatálya alá eső tevékenységekre vonatkozik, az említett állampolgárok egyéb munkát még ideiglenesen sem láthatnak el Magyarországon..$^{53} \mathrm{~A}$ lista mindenesetre rendkívül vegyes összetételü. Az egyszerű fizikai munkáktól a mezőgazdasági, egészségügyi területeken át az olyan, magas bérrel és presztízzsel járó szakmák is megtalálhatóak rajta, mint a pilóta és a légiutas-kísérő. A lista alakulása, bővülése nyilván szoros összefüggésben volt a koronavírus járvány előtti munkaerő-hiánnyal. ${ }^{54} \mathrm{~A}$ munkavállalás engedélymentessége azonban nem jelenti azt, hogy - föszabály szerint - tartózkodási engedélyre ne lenne szükség, amely legfeljebb kétéves időszakra kapható meg. ${ }^{55}$

A harmadik kivétel szerint a kilencven napot meg nem haladó tervezett tartózkodásra jogosító vízummal rendelkező harmadik országbeli állampolgár, valamint az EU 2018/1806 rendeletének ${ }^{56}$ II. mellékletében szereplő harmadik ország állampolgáraként Magyarország területén jogszerüen tartózkodó személy engedélymen-

49 1991. évi IV. törvény a foglalkoztatás elősegítéséről és a munkanélküliek ellátásáról (a továbbiakban: Flt.) 58. § (7) bek. Az Európai Parlament és a Tanács 2014/36/EU irányelve (2014. február 26.) a harmadik országbeli állampolgárok idénymunkásként való munkavállalás céljából való belépésének és tartózkodásának feltételeiről. HL L 94, 2014.3.28., 375-390., 3. cikk.

50 Korm. rend. 2/A. § (1) bek.

51 Korm. rend. 7. § (1) és (3) bek.

52 Korm. rend. 15. $\S(1)$ bek. 26. pont.

53 Korm. rend. 15. $\S(2)$ bek.

${ }^{54}$ DAJNOKı Krisztina-SıPos Norbert-Kőmíves Miklós Péter-HÉDER-RıMA Mária: Mobilitás a határmenti régiókban: Ukrajna. Pécsi Munkajogi Közlemények, 2020/Különszám, 88-89., 95.

55 Harmtv. 16. § (2) bek.

${ }^{56}$ Az Európai Parlament és a Tanács (EU) 2018/1806 rendelete (2018. november 14.) a külső határok átlépésekor vízumkötelezettség alá eső, illetve az e kötelezettség alól mentes harmadik országbeli állampolgárok országainak felsorolásáról. HL L 303, 2018.11.28., 39-58. 
tesen folytathat keresőtevékenységet. ${ }^{57}$ Ezekben az esetekben a magyarországi munkavégzés nem kötött sem összevont, sem munkavállalási engedélyhez, ezért a fent ismertetett kizáró szabályok sem alkalmazandóak. Így nincs akadálya a munkaerő-kölcsönzésen keresztüli foglalkoztatásnak sem.

Az utolsó, negyedik kivétel szerint a más EGT-tagállamban letelepedett kölcsönbeadó is engedélymentesen kölcsönözhet magyarországi kölcsönvevőhöz harmadik állambeli állampolgárt. ${ }^{58} \mathrm{~A}$,másodlagos szabad mozgás jogát” tehát a magyar szabályozás is biztosítja.

Figyelmet érdemel ugyanakkor, hogy ez megfordítva már nem áll fenn: föszabály szerint a Magyarországon letelepedett kölcsönbeadó az általa foglalkoztatott harmadik országbeli állampolgárt más uniós tagállamba nem kölcsönözheti ki. Ez abból ered, hogy az összevont engedély vagy a munkavállalási engedély kifejezetten a Magyarország területén való tartózkodásra jogosít, amely alapján más tagállamba utazni és ott munkát végezni nem lehet. ${ }^{59} \mathrm{~A}$ szerb és ukrán kölcsönzött munkavállalók engedélymentes foglalkoztatása is kifejezetten csak magyarországi munkavégzésre irányulhat. ${ }^{60}$ Arra sem kerülhet sor, hogy a harmadik állambeli állampolgárt a magyarországi kölcsönvevő utasítsa egy másik tagállamban letelepedett munkáltatónál való munkavégzésre, a magyar munkajog ugyanis - kivételt nem türően - tiltja a továbbkölcsönzést, azaz a kölcsönvevő a munkavállalót más munkáltatónál történő munkavégzésre nem kötelezheti. ${ }^{61}$

Más a helyzet azonban a kilencven napot meg nem haladó tervezett tartózkodásra jogosító vízummal rendelkezők és az EU 2018/1806 rendeletének II. mellékletében szereplő harmadik országbeli állampolgárok esetén. Mivel esetükben a magyarországi munkavégzés nem egy konkrét munkakör vagy konkrét munkáltató vonatkozásában engedélyezett - hiszen egyáltalán nincs engedélyeztetési folyamat -, annak sincs akadálya, hogy e harmadik állambeli állampolgárokat a magyar kölcsönbeadó egy további uniós tagállamba kölcsönözze ki.

Végül meg kell vizsgálni azt az esetet is, ha a harmadik állambeli munkavállalót egy harmadik állambeli kölcsönbeadó kölcsönzi ki Magyarországra. Ezt az uniós jog nem tiltja, a kiküldetési irányelv csak annyit ír elö, hogy a nem tagállambeli vállalkozások nem részesülhetnek kedvezőbb bánásmódban, mint a más tagállamban letelepedettek. ${ }^{62}$ Ennyiben tehát az irányelv a harmadik államokra is alkalmazandó. ${ }^{63}$ Ugyanakkor a magyar szabályozásból az következik, hogy Magyarországra harmadik állambeli kölcsönbeadó nem kölcsönözhet ki munkavállalót. A munka törvénykönyvéröl szóló 2012. évi I. törvény (a továbbiakban: Mt.) ugyanis elöírja, hogy kölcsönbeadó csak EGT-államban székhellyel rendelkező vállalkozás lehet, amely megfelel az Mt.-ben vagy az egyéb jogszabályban foglalt feltételeknek, és az állami

\footnotetext{
${ }^{57}$ Harmtv. 7/A. §.

58 Korm. rend. 15. § (1) bek. 8. pont.

${ }^{59}$ Harmtv. 2. § v) pont, 13. §, 16. §.

${ }^{60}$ Korm. rend. 15. $\S(1)$ bek. 26. pont.

${ }^{61}$ Mt. 216. § (2) bek.

62 Kiküldetési irányelv 1. cikk (4) bek.

63 SCHIELRE, Florian: 1996/71/EC: Posting of Workers. In: Schlachter, Monika (szerk.): EU Labour Law: A Commentary. Wolters Kluwer, 2015, 171.
} 
foglalkoztatási szerv nyilvántartásba vette. ${ }^{64}$ Belföldi székhely hiányában tehát a kölcsönbeadó nem nyújthat szolgáltatást Magyarországon. ${ }^{65}$ Annak viszont nincs akadálya, hogy a magyar székhelyű kölcsönbeadó a harmadik országbeli partnercégein keresztül végezze a toborzást, és kössön aztán maga munkaszerződést a harmadik állambeli munkavállalókkal, magyarországi kikölcsönzés céljából. ${ }^{66}$

\section{A harmadik állambeli kölcsönzött munkavállalók jogállása Magyarországon}

A fentieket összefoglalva, egy harmadik állambeli állampolgár kölcsönzésen keresztül csak kivételesen dolgozhat Magyarországon. Erre lehetősége van akkor, ha egy magyar kölcsönbeadó foglalkoztatja szezonális munka keretében, vagy szerb, illetve ukrán állampolgárként a külön közleményben meghatározott foglalkozást végzi, illetve a kilencven napot meg nem haladó tervezett tartózkodásra jogosító vízummal rendelkezők és az EU 2018/1806 rendeletének II. mellékletében szereplő harmadik országbeli állampolgárok esetén.

A magyar jog kifejezetten tiltja az állampolgárságon alapuló diszkriminációt, ${ }^{67}$ ezért a kölcsönbeadók és kölcsönvevök sem tehetnek különbséget a harmadik állambeli és a magyar munkavállalók között. Az Mt. hatálya állampolgárságtól függetlenül minden munkavállalóra kiterjed, aki a munkát rendszerint Magyarországon végzi. ${ }^{68}$ Ugyanakkor a magyar munkajogi szabályozás gyakorlatilag egyáltalán nem tartalmaz olyan speciális rendelkezéseket, amelyek kifejezetten a harmadik állampolgárok magyarországi munkavégzését segítenék elő (például elszállásolásuk, tájékoztatásuk, hazautazásuk vonatkozásában). Az Mt. egyetlen speciális rendelkezése szerint az olyan személy esetén, aki nem érti azt a nyelvet, amelyen az írásbeli nyilatkozatát tartalmazó okirat készült, az írásbeli jognyilatkozat érvényességének feltétele az is, hogy magából az okiratból kitünjön, hogy annak tartalmát a tanúk egyike vagy a hitelesítő személy a nyilatkozó félnek felolvasta és megmagyarázta. ${ }^{69} \mathrm{Az}$ általános együttmüködési kötelezettségböl ${ }^{70}$ azonban álláspontom szerint következik, hogy a munkáltató köteles az általa foglalkoztatott harmadik országbeli állampolgár részére minden tájékoztatást megadni, ami a magyarországi jogszerủ életviteléhez és a munkaviszonybeli kötelezettségei teljesítéséhez szükséges.

\footnotetext{
${ }^{64}$ Mt. 215. § (1) bek.

${ }^{65}$ A hatósági nyilvántartásba vétel számos további feltételt kíván meg, köztük azt, hogy a kölcsönbeadónak a tevékenység gyakorlásához megfelelő irodahelyiséggel kell rendelkeznie, mégpedig Magyarország területén. Részletesen lásd: a munkaerö-kölcsönzési és a magán-munkaközvetítői tevékenység nyilvántartásba vételéröl és folytatásának feltételeiről szóló 118/2001. (VI. 30.) Korm. rendelet 5. § (2) bek., 17/F. § (3) bek.

${ }^{66}$ Ahogy ez például Szerbiában is megvalósul, lásd: SLAVIC, Agneš-SıPos Norbert: Mobilitás a határmenti régiókban - Szerbia. Pécsi Munkajogi Közlemények, 2020/Különszám, 142.

${ }^{67}$ Az egyenlő bánásmódról és az esélyegyenlőség előmozdításáról szóló 2003. évi CXXV. törvény 8. § d) pont, Mt. 12. §. A harmadik állambeli állampolgárok egyenlő bánásmódhoz való jogát az uniós jog is előírja, lásd 2011/98/EU irányelv 12. cikk.

${ }^{68}$ Mt. 3. § (1) bek.

${ }^{69}$ Mt. 22. $\S(7)$ bek.

${ }^{70}$ Mt. 6 . § (2) bek.
} 
Ez kiterjed a munkáltatói utasítások, szabályzatok, a munkaidő-nyilvántartás, a bérelszámolás tartalmának pontos ismertetésére, a munkavállaló által értett nyelven, de ide értendő a munkavállalókat megillető jogokról adandó tájékoztatás is. Az ukrán és szerb állampolgárok magyarországi foglalkoztatására vonatkozó empirikus vizsgálatok mindenesetre hangsúlyozzák e tájékoztatás fontosságát. ${ }^{71}$

A munkáltató ugyan a harmadik állambeli állampolgároknak is köteles költségtérítést biztosítani havonta négyszer a hazautazáshoz, ennek összege azonban korlátozott, 2021-ben például $39730 \mathrm{Ft}$-ban. ${ }^{72} \mathrm{Ez}$ az összeg nyilvánvalóan a belföldi viszonylatban hazautazó munkavállaló esetén jelentheti a ténylegesen felmerült költségek jelentős arányának térítését, de akár csak a szomszédos államokból utazók számára már nem. Az ukrán munkavállalók magyarországi kölcsönzésével kapcsolatos tapasztalatok azt mutatják, hogy sok esetben a szállás és utazás költségeit a kölcsönbeadó cégek vállalják. ${ }^{73}$

A fent említett szabály alapján harmadik állambeli állampolgár külföldi kölcsönbeadón keresztül csak akkor dolgozhat Magyarországon, ha a kölcsönbeadó székhelye egy EGT-tagállamban van. Ebben az esetben kiküldött munkavállalónak minősül. A magyar szabályozás nem tesz különbséget a Magyarországra kiküldött munkavállalókra alkalmazandó munkafeltételek tekintetében aszerint, hogy a munkavállaló EGT-tagállamból vagy harmadik államból érkezik-e. Ezért a külföldi kölcsönbeadó által kikölcsönzött harmadik állambeli állampolgárokra is a kiküldetési irányelv szerinti munkafeltételeket kell alkalmazni, ha ez kedvezőbb, mint az egyébként irányadó jog. ${ }^{74}$

A magyar társadalombiztosítás hatálya kiterjed Magyarország állampolgáraira és a Magyarországon munkát végző más természetes személyekre is. ${ }^{75}$ Ezért föszabály szerint a Magyarországon dolgozó harmadik állambeli állampolgárok is biztosítottnak minősülnek, és a társadalombiztosítás valamennyi szolgáltatására jogosultságot szereznek. Ugyanakkor nem esik a magyar társadalombiztosítás hatálya alá a magyar jogszabályok szerint be nem jegyzett külföldi munkáltató által Magyarország területén foglalkoztatott, harmadik állam állampolgárságával rendelkező és külföldinek minősülő munkavállaló, ha a munkavégzésre kiküldetés, kirendelés vagy munkaerö-kölcsönzés keretében kerül sor, feltéve, hogy e munkavégzés a két évet nem haladja meg, és az előző belföldi munkavégzés befejezésétől számítva három

\footnotetext{
${ }^{71}$ DudÁs Katalin-HaLmos Szilvia-KÁRTYÁs Gábor: A munkajog szerepe a munkaerőhiány kezelésében. Kutatási zárótanulmány, Budapest, 2018, 72-74. https://www.liganet.hu/images/a10122/Zrtanulmny-munkaerhiny2018_1. pdf (2021. 05. 18.); FEDYUK, Olena-MESZMANN T. Tibor: Ukrán kölcsönzött dolgozók az elektronikai ágazatban. Esettanulmány: Magyarország. AnBlokk Kultúra- és Társadalomtudományi Egyesület, 2018, 11-14., 18-19. https://anblokkegyesulet.files.wordpress.com/2018/02/web-hu.pdf (2021. 05. 18.). SLAVIC-SIPOS: i. m., 142.

72 A munkába járással kapcsolatos utazási költségtérítésről szóló 39/2010. (II. 26.) Korm. rendelet 3. § (3)-(4) bek.; az innovációért és technológiáért felelős miniszter közleménye a Hivatalos Értesítő 2021. évi 7. számában.

73 DAJNOKI-SıPos-Kömíves-HÉdeR-RIMA: i. m., 92-93.; BıszTRAI Márton-KovÁcs Eszter-Kováts András-VADASI Vivien: Folyamatos ideiglenesség. Migráns munkavállalók helyzete Magyarországon. Friedrich Ebert Stiftung, 2020, 24. http://library.fes.de/pdf-files/bueros/budapest/17064.pdf (2021. 05. 18.).

${ }^{74}$ Mt. 295. §.

${ }^{75}$ A társadalombiztosítás ellátásaira jogosultakról, valamint ezen ellátások fedezetéről szóló 2019. évi CXXII. törvény (a továbbiakban: Tbj.) 1. § (1) bek.
} 
év eltelt. ${ }^{76}$ Ezekben az esetekben a munkavállaló annak az országnak a biztosítási rendszere alatt marad, ahonnan Magyarországra kiküldték (kölcsönözték). Álláspontom szerint a kivétel célja világos: lényegében a szociális biztonsági koordináció kiküldetési kivételét terjeszti ki a harmadik államokra is. A jogszabály szövegezése azonban elavult, hiszen a kiküldetés, kirendelés fogalmakat a magyar munkajog az Mt. hatálybalépése óta nem használja. ${ }^{77}$ Így egyáltalán nem világos, hogy a három fogalmat (kiküldetés, kirendelés, kölcsönzés) miként kell elhatárolni. Ehelyett célszerü lenne a szabályt úgy megfogalmazni, hogy az - a munkaerö-kölcsönzés mellett - a harmadik állambeli munkáltató által határon átnyúló szolgáltatásnyújtás teljesítése keretében a magyarországi foglalkoztatónál magánjogi szerződés teljesítése érdekében történő munkavégzés esetén alkalmazandó, vagy akkor, ha a munkavállaló foglalkoztatását a harmadik állambeli munkáltató ellenérték nélkül engedi át a vele tulajdonosi kapcsolatban áló magyarországi munkáltatónak.

A harmadik állam állampolgára egyes szociális ellátásokra is jogosult lehet. ${ }^{78}$ Egyrészt valamennyi álláskeresési ellátásra, ha összevont kérelmezési eljárás alapján kiadott tartózkodási engedéllyel rendelkezik és Magyarországon legalább hat hónapig munkaviszonyban állt. ${ }^{79}$ Másrészt valamennyi családtámogatási ellátásra, ha összevont engedéllyel rendelkezik, és a munkavállalást számára hat hónapot meghaladó időtartamra, de a vállalaton belül áthelyezett személy esetén legalább kilenc hónapra engedélyezték. Ettől eltérően, a magas szintű képzettséget igénylő munkavállalás és tartózkodás céljából kiállított engedéllyel (EU Kék Kártyával) rendelkező harmadik országbeli állampolgár valamennyi családtámogatási ellátásra jogosult, kivéve az anyasági támogatást. ${ }^{80}$ Harmadrészt a szociális törvény szerinti időskorúak járadékára is jogosult, ha EU Kék Kártyával, összevont engedéllyel vagy az EU 2016/801 irányelvének ${ }^{81}$ hatálya alá tartozó tartózkodási engedéllyel rendelkezik. ${ }^{82}$

Mivel a kölcsönzött munkavállalók magyarországi foglalkoztatása nem összevont engedéllyel vagy EU Kék Kártyával történik, illetve nem esnek az EU 2016/801 irányelvének hatálya alá, a felsorolt ellátásokra nem szerezhetnek jogosultságot.

Meg kell jegyezni, hogy a harmadik országok állampolgárainak magyarországi szociális ellátásait kétoldalú nemzetközi egyezmények is alakíthatják, amelyek a társadalombiztosítási törvénytöl eltérő szabályokat tartalmazhatnak. ${ }^{83}$ Jellemzően e megállapodások alapján a Magyarországra kiküldött munkavállaló nem két évig, hanem hosszabb ideig marad a kiküldő állam társadalombiztosítási rendszerének

\footnotetext{
76 Tbj. 17. § (2) bek. a) pont.

77 GERgely Katalin-KISS Zoltán: Kommentár a társadalombiztositás ellátásaira jogosultakról, valamint ezen ellátások fedezetéről szóló 2019. évi CXXII. törvényhez. Wolters Kluwer, 2020. Lásd a 17. §-hoz füzött magyarázatot.

${ }^{78}$ Lásd még: 2011/98/EU irányelv 12. cikk (2) bek. b) pont; 2014/36/EU irányelv 23. cikk (2) bek. i) pont.

${ }^{79}$ Flt. 2. § (3) bek.

${ }^{80}$ A családok támogatásáról szóló 1998. évi LXXXIV. törvény 2. § ae-af) pontok.

${ }^{81}$ Az Európai Parlament és a Tanács (EU) 2016/801 irányelve (2016. május 11.) a harmadik országbeli állampolgárok kutatás, tanulmányok folytatása, gyakorlat, önkéntes szolgálat, diákcsereprogramok vagy oktatási projektek és au pair tevékenység céljából történő beutazásának és tartózkodásának feltételeiről. HL L 132, 2016.5.21., 21-57.).

$58 \quad{ }^{2}$ A szociális igazgatásról és szociális ellátásokról szóló 1993. évi III. törvény 3. § (4), (4c) és (4d) bek.

83 Tbj. 3. §.
} 
hatálya alatt. Ezeket a speciális szabályokat az alábbi táblázat foglalja össze azzal, hogy mivel harmadik állambeli székhelyủ kölcsönbeadó Magyarországra nem nyújthat szolgáltatást, e szabályoknak a kölcsönzés szempontjából nincs relevanciája.

2. táblázat. A kiküldetés idejére vonatkozó rendelkezések kétoldalú társadalombiztosítási egyezményekben

\begin{tabular}{|c|c|c|}
\hline Ország & A kiküldetés ideje & Jogszabályhely \\
\hline Ausztrália & 4 év & $\begin{array}{l}\text { 2011. évi CXVII. törvény, } \\
\text { 7. cikk }\end{array}$ \\
\hline Kanada & 5 év & $\begin{array}{l}\text { 2003. évi LIX. törvény, } \\
\text { 7-8. cikk }\end{array}$ \\
\hline India & 5 év & $\begin{array}{l}\text { 2010. évi XXIX. törvény, } \\
\text { 8. cikk }\end{array}$ \\
\hline Japán & 5 év & $\begin{array}{l}\text { 2013. évi CLII. törvény, } \\
\text { 7. cikk }\end{array}$ \\
\hline Orosz Föderáció & $\begin{array}{l}2 \text { év, amely a nemzeti hatóságok } \\
\text { megegyezése alapján } 5 \text { évig meg- } \\
\text { hosszabbítható, vagy kivételesen } \\
\text { az adott tevékenység végéig. }\end{array}$ & $\begin{array}{l}\text { 2020. évi XIV. törvény, } \\
\text { 9. cikk }\end{array}$ \\
\hline Dél-Korea & 3 év & $\begin{array}{l}\text { 2006. évi LXXIX. törvény, } \\
\text { 7. cikk }\end{array}$ \\
\hline Törökország & $\begin{array}{l}2 \text { év, amely } 5 \text { évig meghosszabbít- } \\
\text { ható a nemzeti hatóságok meg- } \\
\text { egyezése alapján }\end{array}$ & $\begin{array}{l}\text { 2015. évi XXX. törvény, } \\
\text { 9. cikk }\end{array}$ \\
\hline USA & 5 év & $\begin{array}{l}\text { 2015. évi XXIX. törvény, } \\
\text { 5. cikk }\end{array}$ \\
\hline
\end{tabular}

Forrás: saját szerkesztés

\section{6. Összegzés}

A határon átnyúló munkaerő-kölcsönzésnél a két alapvető vizsgálandó kérdés, hogy a másik állambeli munkavállaló jogosult-e munkát vállalni a kölcsönbeadó országában, illetve hogy a kölcsönbeadó jogosult-e munkaerő-kölcsönzési szolgáltatást nyújtani a kölcsönvevő országába. Ezek a kérdések még az uniós tagállamok vonatkozásában sem teljesen világosak - a határon átnyúló munkavállalás és szolgáltatásnyújtás szabadsága ellenére -, amit jól mutat az EUB folyamatos jogértelmező tevékenysége.

Magyarország a harmadik államokból kiinduló munkaerő-kölcsönzés tekintetében meglehetősen elzárkózó szabályozást alakított ki. Egyrészt a harmadik országbeli állampolgár magyarországi foglalkoztatása kölcsönzés keretében főszabály szerint nem engedélyezhető, másrészt a harmadik államban székhellyel rendelkező kölcsönbeadó Magyarországra nem nyújthat szolgáltatást. Ez az óvatos hozzáállás 
indokolható a munkaerö-kölcsönzés összetett felépítésével, a megosztott munkáltatói pozíció ugyanis jelentősen megnehezítheti a foglalkoztatás engedélyeztetésére, a munkavállalói jogokra vagy a társadalombiztosításra vonatkozó szabályok megtartásának ellenőrzését. Ugyanakkor a kivételek bővülésének köszönhetően ezekkel a tényállásokkal egyre gyakrabban találkozhatunk, az uniós jogból következően pedig tagállami hatáskörben nem is korlátozható, hogy egy másik tagállamban jogszerủen tartózkodó és ott munkát vállaló harmadik állambeli állampolgár kölcsönzésen keresztül dolgozzon Magyarországon. A szabályozás lazítására mindenesetre csak akkor kerülhet sor, ha egyúttal biztosított a jogi megfelelés ellenőrzéséhez szükséges apparátus is. 